\title{
AMPLIFIED SPONTANEOUS EMISSION INDUCED PECULIARITIES OF THE PASSIVELY Q-SWITCHED DIODE PUMPED ERBIUM LASER DYNAMICS
}

\author{
M.V. Bogdanovich 2 , A.V. Grigor'ev日, V.V. Kabanov日, Y.V. Lebiadok日, \\ G.I. Ryabtsev 国, A.G. Ryabtsev b, M.A. Shchemelevb, A.S. Dementjeve, L. Agrawal \\ and A. Bhardwajd \\ ${ }^{a}$ B.I. Stepanov Institute of Physics, National Academy of Sciences of Belarus, Nezalezhnasti Ave. 68, Minsk 220072, Belarus \\ E-mail: ryabtsev@dragon.bas-net.by \\ ${ }^{\mathrm{b}}$ Belarusian State University, Nezalezhnasti Ave. 4, Minsk 220030, Belarus \\ ' Institute of Physics, Center for Physical Sciences and Technology, Savanoriu Ave. 231, LT-02300 Vilnius, Lithuania \\ ${ }^{\mathrm{d}}$ Laser Science and Technology Centre (LASTEC), Metcalfe House Delhi 110 054, India
}

Received 25 October 2010; revised 10 December 2010; accepted 15 December 2010

\begin{abstract}
The influence of amplified spontaneous emission (ASE) on the dynamic characteristics of transversely diode pumped erbiumytterbium glass laser with Co:spinel Q-switch has been investigated. ASE cavity loss coefficient for passively Q-switched laser has been determined. The dependences of ASE cavity loss coefficient on the active element length, output mirror reflection coefficient, and initial transmission of the passive Q-switch have been defined. Laser dynamics has been modelled on the basis of the rate equation set for ion population densities and photon numbers, taking into account the amplified spontaneous emission. It has been shown that ASE accounting does not influence significantly the energy and duration of the output laser pulse. Variations of the laser turn-on time and pulse repetition rate of about 5-10\% have been revealed in the case of ASE taken into consideration.
\end{abstract}

Keywords: amplified spontaneous emission, erbium glass laser, diode pumping, passive Q-switch

PACS: 42.55.Xi, 42.60.Mi

\section{Introduction}

Erbium glass based solid-state lasers are promising light sources for various applications, such as eyesafe range-finding, target designating, and remote sensing $[1-4]$. Compact high efficiency diode pumped lasers are required for modern optical systems. Passive Q-switch application for laser pulse generation is preferable for portable and low power consumption laser heads [5, 6]. Development and optimization of passively Q-switched lasers with specified output radiation dynamical characteristics require adequate modelling of the laser mode evolution within the cavity. There are many effects, for example, laser media thermalization, slow Q-switching, effects of absorber lifetime, considered during the numerical modelling of passively Q-switched laser operation [7, 8]. Amplified spontaneous emission (ASE), often referred to as amplified luminescence, is one of the factors that can affect significantly the laser threshold, power, and tem- poral characteristics [9-12]. However, the role of amplified spontaneous emission in dynamics of the passively Q-switched solid-state lasers is not determined properly. This work is devoted to definition of ASE influence on power and temporal output characteristics of eye-safe erbium laser with cobalt-doped spinel Q-switch.

\section{Theoretical model}

Diode pumped Yb, Er:boro-silico-phosphate glass laser, emitting at $1.54 \mu \mathrm{m}$ wavelength, has been investigated. Schematic view of the laser is presented in Fig. 1(a). Cylindrical active element 1 is transversely pumped by $940 \mathrm{~nm}$ laser diode arrays 2 . Erbium laser is Q-switched by means of the $\mathrm{Co}^{2+}: \mathrm{MgAl}_{2} \mathrm{O}_{4}$ saturable absorber 3. The laser cavity is formed by two plane mirrors: high-reflective mirror 4 and output mirror 5 .

Energy level diagrams for the active element and Q-switch doping ions are shown in Fig. 1(b). Pump 
radiation absorption leads to excitation of the $\mathrm{Yb}^{3+}$ ions from the ${ }^{2} \mathrm{~F}_{7 / 2}$ energy level to the ${ }^{2} \mathrm{~F}_{5 / 2}$ state. Then non-radiative energy transfer from $\mathrm{Yb}^{3+}$ to $\mathrm{Er}^{3+}$ ions occurs, resulting in $\mathrm{Er}^{3+}$ ion ${ }^{4} \mathrm{I}_{15 / 2} \rightarrow{ }^{4} \mathrm{I}_{11 / 2}$ transitions. This process is designated by the energy transfer coefficient $k$ on the diagram. Excited $\mathrm{Er}^{3+}$ ions decay quickly from the ${ }^{4} \mathrm{I}_{11 / 2}$ state to the metastable energy level ${ }^{4} \mathrm{I}_{13 / 2}$ in non-radiative manner. Laser transitions occur between ${ }^{4} \mathrm{I}_{13 / 2}$ and ${ }^{4} \mathrm{I}_{15 / 2}$ erbium ion states. Four level system was applied for modelling of $\mathrm{Co}^{2+}: \mathrm{MgAl}_{2} \mathrm{O}_{4}$ saturable absorber. In accordance with Hercher's approach [13], life-times of the levels $\mathrm{SA}_{3}$ and $\mathrm{SA}_{4}$ are considered to be zero.

The rate equation set for ytterbium, erbium, and cobalt ion population densities as well as lasing and amplified spontaneous emission photon numbers within the laser cavity can be written as

$$
\left\{\begin{aligned}
\frac{\mathrm{d} N_{2^{\prime}}}{\mathrm{d} t} & =W_{\mathrm{p}}\left(N_{\mathrm{Yb}}-2 N_{2^{\prime}}\right)-k N_{2^{\prime}} N_{1}-A_{2^{\prime} 1^{\prime}} N_{2^{\prime}} \\
\frac{\mathrm{d} N_{1}}{\mathrm{~d} t} & =\left(\sigma_{\mathrm{a}} N_{2}-\sigma_{\mathrm{e}} N_{1}\right)\left(\Phi_{\mathrm{las}}+\Phi_{\mathrm{ASE}}\right)+A_{21} N_{2} \\
& -k N_{2^{\prime}} N_{1} \\
\frac{\mathrm{d} N_{2}}{\mathrm{~d} t} & =-\left(\sigma_{\mathrm{a}} N_{2}-\sigma_{\mathrm{e}} N_{1}\right)\left(\Phi_{\mathrm{las}}+\Phi_{\mathrm{ASE}}\right) \\
& -A_{21} N_{2}+A_{32}\left(N_{\mathrm{Er}}-N_{2}-N_{1}\right) \\
\frac{\mathrm{d} N_{\mathrm{Co} 1}}{\mathrm{~d} t} & =-\sigma_{\mathrm{gsa}} N_{\mathrm{Co} 1}\left(\Phi_{\mathrm{las}}+\Phi_{\mathrm{ASE}}\right) \\
& +A_{\mathrm{Co}}\left(N_{\mathrm{Co}}-N_{\mathrm{Co} 1}\right) \\
\frac{\mathrm{d} q_{\mathrm{las}}}{\mathrm{d} t} & =c\left[\eta_{\mathrm{a}}\left(\sigma_{\mathrm{a}} N_{2}-\sigma_{\mathrm{e}} N_{1}\right)-k_{\mathrm{las}}\right] q_{\mathrm{las}} \\
& -c \eta_{\mathrm{s}}\left[\sigma_{\mathrm{gsa}} N_{\mathrm{Co} 1}+\sigma_{\mathrm{esa}}\left(N_{\mathrm{Co}}-N_{\mathrm{Co} 1}\right)\right] q_{\mathrm{las}} \\
& +r_{\mathrm{las}}^{\mathrm{sp}}
\end{aligned}\right.
$$

where $N_{1}, N_{2}$ are the $\mathrm{Er}^{3+}$ population densities for ${ }^{4} \mathrm{I}_{15 / 2}$ and ${ }^{4} \mathrm{I}_{13 / 2}$ energy levels respectively; $N_{2^{\prime}}$ is the $\mathrm{Yb}^{3+}$ population density for ${ }^{2} \mathrm{~F}_{5 / 2}$ energy level; $N_{\mathrm{Co} 1}$ is the $\mathrm{Co}^{2+}$ population density for $\mathrm{SA}_{1}$ energy level; $N_{\mathrm{Yb}}, N_{\mathrm{Er}}, N_{\mathrm{Co}}$ are the $\mathrm{Yb}^{3+}, \mathrm{Er}^{3+}$, and $\mathrm{Co}^{2+}$ ion densities respectively; $W_{\mathrm{p}}$ is the pump rate; $A_{2^{\prime} 1^{\prime}}$ is the de-excitation rate related to transitions from ${ }^{2} \mathrm{~F}_{5 / 2}$ to ${ }^{2} \mathrm{~F}_{7 / 2}$ ytterbium energy levels; $\sigma_{\mathrm{a}}, \sigma_{\mathrm{e}}$ are the absorption and emission cross-sections for ${ }^{4} \mathrm{I}_{13 / 2}{ }^{4} \mathrm{I}_{15 / 2}$ transition respectively; $\Phi_{\text {las }}$ and $\Phi_{\mathrm{ASE}}$ are the lasing and amplified spontaneous emission photon fluxes respec- tively; $A_{21}$ is the de-excitation rate related to transitions from the ${ }^{4} \mathrm{I}_{13 / 2}$ to ${ }^{4} \mathrm{I}_{15 / 2}$ erbium energy levels; $A_{32}$ is the de-excitation rate related to transitions from the $\mathrm{Er}^{3+}{ }^{4} \mathbf{I}_{11 / 2}$ state to the ${ }^{4} \mathbf{I}_{13 / 2}$ state; $\sigma_{\mathrm{gsa}}, \sigma_{\mathrm{esa}}$ are the ground and excited state absorption cross-sections of the $\mathrm{Co}^{2+}$ ion; $A_{\mathrm{Co}}$ is the de-excitation rate of the cobalt ion first excited state; $q_{\text {las }}, q_{\mathrm{ASE}}$ are the lasing and amplified spontaneous emission number of photons; $k_{\text {las }}$ and $k_{\mathrm{ASE}}$ are the lasing and amplified spontaneous emission cavity loss coefficients. The following designations were applied for the equation set (1): $r_{\text {las }}^{\mathrm{sp}}=\delta_{\text {las }} A_{21} N_{2} L_{\mathrm{a}} S_{\mathrm{m}}$ and $r_{\mathrm{ASE}}^{\mathrm{sp}}=\delta_{\mathrm{ASE}} A_{21} N_{2} L_{\mathrm{a}} S_{\mathrm{m}}$ are the spontaneous emission rate contributions into the lasing and ASE photon number rates, where $\delta_{\text {las }}$, $\delta_{\mathrm{ASE}}$ are the lasing and amplified spontaneous emission factors respectively, $L_{\mathrm{a}}, L_{\mathrm{s}}$ are the active element and passive shutter optical lengths, $S_{\mathrm{m}}$ is the lasing mode cross-section area; $c$ is the speed of light in vacuum; $\eta_{\mathrm{a}}=L_{\mathrm{a}} / L_{\mathrm{opt}}$ and $\eta_{\mathrm{a}}=L_{\mathrm{s}} / L_{\mathrm{opt}}$ are the ratios of the active element $\left(L_{\mathrm{a}}\right)$ and saturable absorber $\left(L_{\mathrm{s}}\right)$ optical lengths to the cavity optical length $L_{\mathrm{opt}}$ respectively.

The photon fluxes $\Phi_{\text {las }}$ and $\Phi_{\mathrm{ASE}}$ distributions over the cavity are considered to be uniform and the following expressions can be used for calculations: $\Phi_{\text {las }}=$ $c q_{\mathrm{las}} /\left(L_{\mathrm{opt}} S_{\mathrm{m}}\right)$ and $\Phi_{\mathrm{ASE}}=c q_{\mathrm{ASE}} /\left(L_{\mathrm{opt}} S_{\mathrm{m}}\right)$.

The first four equations in (1) describe the ytterbium, erbium, and cobalt population density evolutions taking into account the conditions $N_{\mathrm{Yb}}=N_{1^{\prime}}+N_{2^{\prime}}, N_{\mathrm{Er}}=$ $N_{1}+N_{2}+N_{3}, N_{\mathrm{Co}}=N_{\mathrm{Co} 1}+N_{\mathrm{Co} 2}$, where $N_{\mathrm{Co} 2}$ is the cobalt ion population density for $\mathrm{SA}_{2}$ energy level. The processes of up-conversion, erbium excited state absorption, cross-relaxation, and back energy transfer from erbium to ytterbium are not considered because of insignificant influence on $\mathrm{Er}, \mathrm{Yb}$ :glass laser dynamics [14].

Dynamics of ASE and lasing radiation within the laser cavity is modelled by two similar rate equations written in terms of photon numbers. The conditions of the lasing and ASE radiation evolution differ in spontaneous emission factors $\delta_{\text {las }}, \delta_{\mathrm{ASE}}$ and loss coefficients $k_{\text {las }}, k_{\mathrm{ASE}}$. Values of these factors were selected to be $\delta_{\text {las }}=0.001, \delta_{\mathrm{ASE}}=0.38$ [12]. The loss coefficient $k_{\text {las }}$ magnitude was calculated using a standard approach [15] applied for the laser cavity under investigation. ASE cavity loss coefficient $k_{\mathrm{ASE}}$ was determined according to the technique based on the analysis of radiation distribution over the laser cavity and the luminescence balance equation written for steady-state conditions [12].

Initial transmission of the passive shutter was taken into account in addition to the reflection coefficient of 

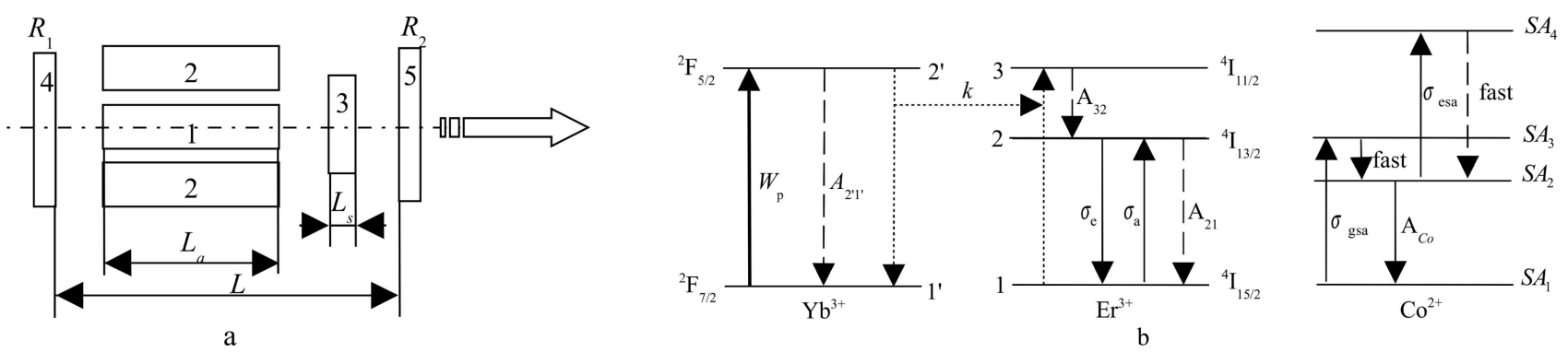

Fig. 1. Schemes of (a) laser and (b) energy levels. 1 is the Yb, Er:glass active element, 2 are the diode arrays, 3 is the saturable absorber, 4 and 5 are the high-reflective and output mirrors respectively; $L_{\mathrm{a}}, L_{\mathrm{s}}, L$ are active element, saturable absorber, and cavity lengths respectively; $R_{1}, R_{2}$ are the reflection coefficients of the high-reflective and output mirrors respectively.

the mirrors for modelling of radiation dynamics. Thus analysed laser systems were characterized by a factor $\xi=R_{2} T_{0}^{2}$, where $R_{2}$ is the reflection coefficient of the output mirror, $T_{0}$ is the initial transmission of the saturable absorber.

\section{Results and discussion}

Transversely diode pumped Yb, Er:boro-silicophosphate glass laser with the cavity length of 25$100 \mathrm{~mm}$ was investigated. Glass rod length was varied from 10 to $50 \mathrm{~mm}$. Diameter of the cylindrical active element was assumed to be $1 \mathrm{~mm}$. Active medium ytterbium and erbium doping concentrations were selected to be $4 \cdot 10^{27}$ and $5 \cdot 10^{25} \mathrm{~m}^{-3}$, respectively. $\mathrm{Yb}$, Er:glass and $\mathrm{Co}: \mathrm{MgAl}_{2} \mathrm{O}_{4}$ passive Q-switch parameters were taken from [12] and [16] respectively.

Two-side transverse pumping of the cylindrical glass active element was assumed. Maximum power of the one side $940 \mathrm{~nm}$ diode pumping arrangement was considered to be $50 \mathrm{~W}$ per $10 \mathrm{~mm}$ length. Pump radiation absorption by active medium was supposed to be $70 \%$. Uniform pump power distribution over the active element was accepted. Therefore the lasing mode crosssection diameter was taken to be equal to that of the glass rod.

Modelling of the laser radiation evolution was realized on the basis of the rate equation set (1). RungeKutta four-order method was applied for solving the equation set (1) numerically. Amplified spontaneous emission cavity loss coefficient $k_{\mathrm{ASE}}$ values were determined for performing theoretical simulation of the laser dynamics. Coefficient $k_{\text {ASE }}$ was evaluated for different active element lengths $(10-50 \mathrm{~mm})$, reflection coefficients $(0.65-0.95)$ of the output mirror, and initial transmissions (from 0.75 to 0.95 ) of the passive Q-switch. An inverse proportionality between $k_{\mathrm{ASE}}$ coefficient and active element length was revealed: $k_{\mathrm{ASE}}=\Delta / L_{\mathrm{a}}$, where $\Delta$ is the proportionality coefficient. Typical

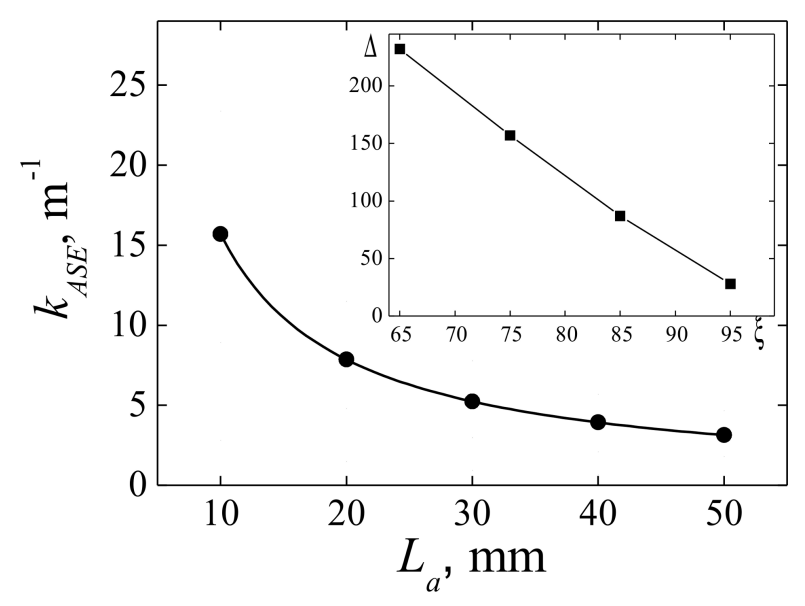

Fig. 2. Amplified spontaneous emission cavity loss coefficient as function of active element length at $\xi=0.75$. Inset shows the dependence of coefficient $\Delta$ on the factor $\xi$.

$k_{\mathrm{ASE}}\left(L_{\mathrm{a}}\right)$ curve, obtained for the cavity length $L=$ $100 \mathrm{~mm}$ and factor $\xi=0.75$, is presented in Fig. 2 . Inset of Fig. 2 shows the dependence of proportionality coefficient $\Delta$ on $\xi$ factor. It can be seen that $\Delta(\xi)$ can be approximated by linear function.

Theoretical investigations were performed with and without ASE accounting to reveal the role of amplified spontaneous emission in the passively Q-switched laser dynamics. Typical time dependences of erbium ${ }^{4} \mathrm{I}_{13 / 2}$ energy level population density and output power for the laser with $L_{\mathrm{a}}=30 \mathrm{~mm}, L=100 \mathrm{~mm}$, and $\xi=0.4$ are presented in Fig. 3. It can be seen that ASE leads to a rise of time interval required for realizing the population density threshold conditions. Therefore the increase of the laser turn-on time $t^{1}$ corresponding to the laser pulse appearance moment is revealed. ASE induced variations of the laser turn-on time can be characterized by the laser pulse delay $\Delta t=t_{2}^{1}-t_{1}^{1}$, where $t_{1}^{1}, t_{2}^{1}$ are the laser turn-on times without and with ASE accounting respectively. Value of the pulse delay $\Delta t$ rises with the pulse number, thus ASE results in a change of the pulse repetition rate. It has been determined that maximum ASE induced variation of the pulse repetition rate ex- 


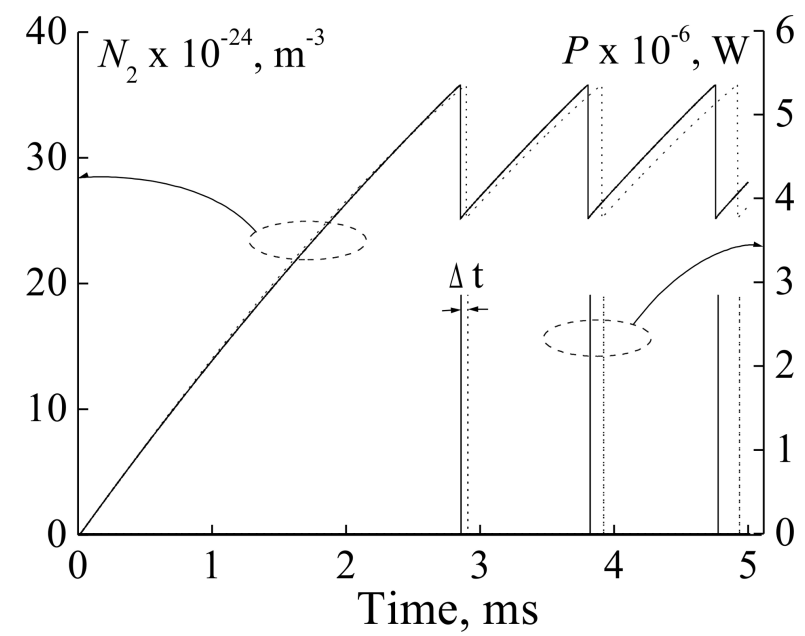

Fig. 3. Time dependence of erbium ${ }^{4} \mathrm{I}_{13 / 2}$ energy level population density $N_{2}$ and output radiation power $P$ with (dotted curves) and without (solid curves) ASE accounting; $t_{1}^{1}, t_{2}^{1}$ are the laser turn-on times without and with ASE accounting respectively, $\Delta t=t_{2}^{1}-t_{1}^{1}$.

ceeds $11 \%$ for $L_{\mathrm{a}}=20 \mathrm{~mm}, L=25 \mathrm{~mm}$, and $\xi=0.4$. At that, the peak power and pulse duration of the laser output radiation remain almost the same. ASE induced peak power variations were less than $1 \%$, pulse duration deviations were not revealed within the accuracy of $0.1 \%$.

Pulse delay induced by ASE can be critical for development of modern single-pulse solid-state laser systems. Such lasers emit single pulses with the frequency set by the pumping modulation.

Theoretical investigation of ASE induced pulse delay dependence on cavity parameters of passively Q-switched erbium glass laser operating in a single-pulse mode was performed. Such laser mode was modelled by means of the pump pulse cutting off after the laser pulse appearance. The results of numerical calculations are presented in Figs. 4 and 5.

Laser turn-on time $t^{1}$ values were determined with and without ASE accounting for different cavity lengths, output mirror reflection coefficients, and initial transmissions of the Q-switch. Figure 4 shows the laser turnon time change with the cavity length variations at constant active element length $L_{\mathrm{a}}=30 \mathrm{~mm}$. It can be seen that the turn-on time rises slightly with the cavity length increase when ASE is excluded from consideration (curve 1). ASE leads to a nonlinear descending $t^{1}(L)$ curve character which can be approximated by exponential function (curve 2 ). In the case of relatively small values of $R_{2}$ and $T_{0}$ (factor $\xi<0.6$ ) the amplified spontaneous emission effect results in an increase of $t^{1}$ magnitude and a delay of the laser pulse, Fig. 4(a). When $\xi \sim 0.7-0.9$, ASE accelerates the laser pulse appearance, making $\Delta t$ negative (Fig. 4(b)). At

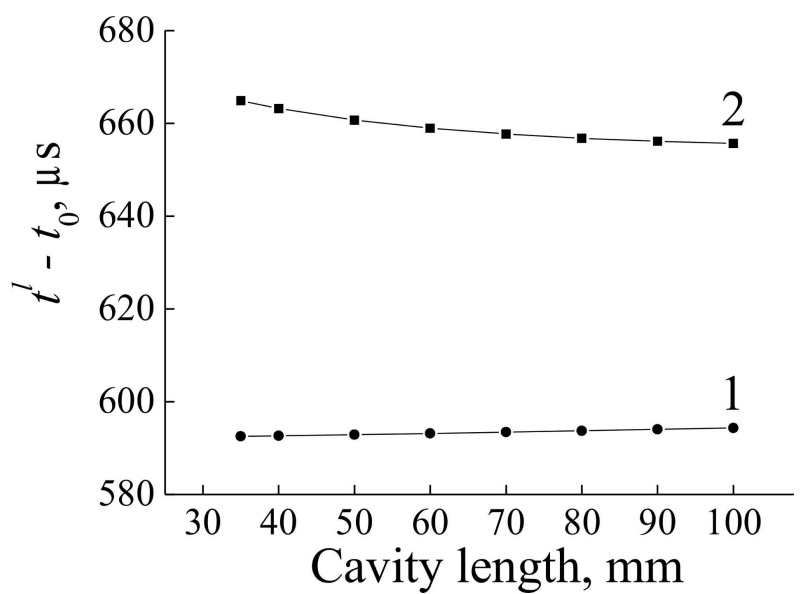

(a)

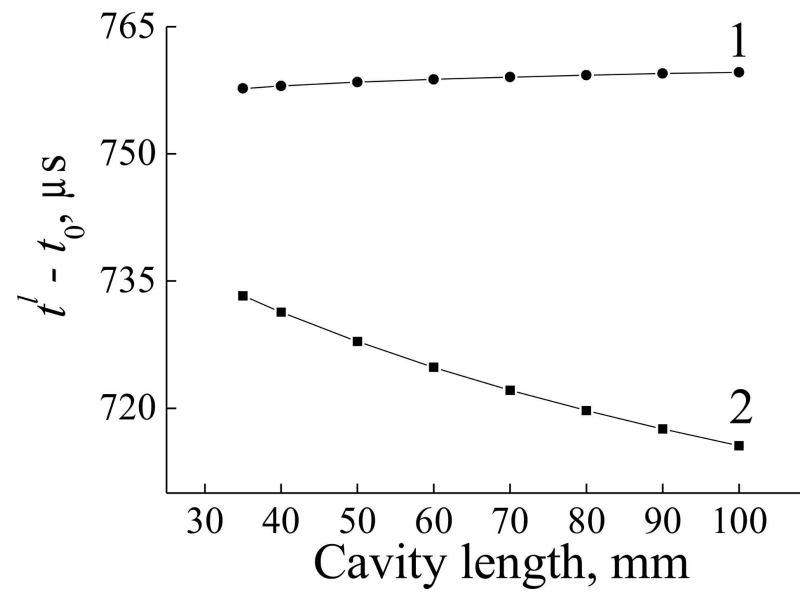

(b)

Fig. 4. Laser turn-on time versus cavity length without ASE (curve 1) and taking into account ASE (curve 2). For convenience the laser turn-on time is presented in the form of the difference $t^{1}-t_{0}$, where the parameter $t_{0}$ is equal to (a) $2 \mathrm{~ms}$ and (b) $1 \mathrm{~ms}$. Parameter $\xi=$ 0.4 in (a) and $\xi=0.8$ in (b).

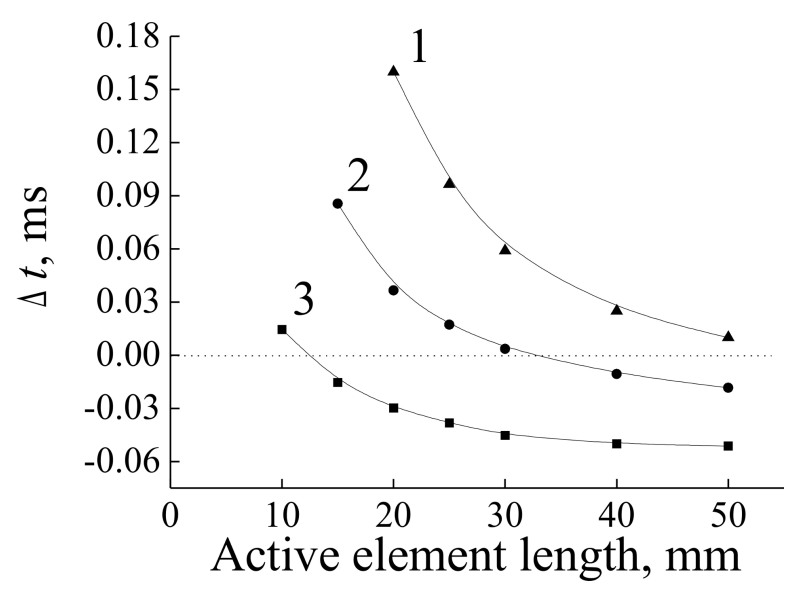

Fig. 5. Laser turn-on delay versus active element length. $\xi=$ $0.4(1), \xi=0.6(2)$, and $\xi=0.8(3)$. 
that, the behaviour of the curves 1 and 2 remains the same. These results are in agreement with [12] where it has been shown that amplified spontaneous emission can both increase and decrease the laser turn-on time depending on the pumping and cavity characteristics.

The dependences of the pulse delay on the active element length at different $\xi$ factors and fixed cavity length $L=100 \mathrm{~mm}$ are shown in Fig. 5. It can be seen that the $\Delta t\left(L_{\mathrm{a}}\right)$ dependences have similar decay character and can be approximated by exponential functions. Thus the active element length influences significantly the moment of the laser pulse appearance. The laser turn-on delay value can be as high as $5 \%$ from $t^{1}$ for relatively small active element lengths $L_{\mathrm{a}} \leq 20 \mathrm{~mm}$ and relatively small values of parameter $\xi \leq 0.4$ (curve 1, Fig. 5). ASE induced turn-on time decrease can be about $0.05 \mathrm{~ms}$ for relatively high active element lengths $L_{\mathrm{a}} \geq 50 \mathrm{~mm}$ and relatively high $\xi \geq 0.8$ (curve 3 , Fig. 5).

\section{Conclusion}

Dynamics of passively Q-switched transversely diode-pumped erbium glass laser has been simulated taking into account amplified spontaneous emission. Modelling was performed on the basis of the rate equation set for erbium, ytterbium, and cobalt ion population densities as well as lasing and ASE photon numbers under the condition of uniform pump, lasing, and ASE photon flux distributions over the cavity. ASE cavity loss coefficient values have been defined for different active element lengths, output mirror reflective coefficients, and passive Q-switch initial transmissions. An inverse proportionality between ASE cavity loss coefficient and active element length has been revealed. It has been determined that the amplified spontaneous emission accounting results in a change of the laser turn-on time up to $5 \%$ as well as pulse repetition rate more than $11 \%$. Laser output radiation peak power and pulse duration are not affected considerably by the ASE flux. Amplified spontaneous emission influence on the diodepumped erbium laser dynamics can be reduced by an appropriate choice of the cavity and passive Q-switch characteristics.

\section{References}

[1] A.Yu. Abazadze, V.N. Bykov, G.M. Zverev, A.A. Pleshkov, and V.A. Simakov, Highly efficient minilaser with transverse nulsed semiconductor pumping for eye-safe iaser range-finding, Quantum Electron. 32(3), 210-212 (2002).
[2] J.E. Nettleton, B.W. Schilling, D.N. Barr, and J.S. Lei, Monoblock laser for a low-cost, eyesafe, microlaser range finder, Appl. Opt. 39(15), 2428-2432 (2000).

[3] W. Zendzian, L. Galecki, J.K. Jabczynski, J. Kwiatkowski, L. Gorajek, M. Nemec, H. Jelinkova, and J. Sulc, Resonantly pumped, high peak power Er:YAG laser, Laser Phys. 20(2), 470-473 (2010).

[4] A.J. McGrath, J. Munch, G. Smith, and P. Veitch, Injection-seeded, single-frequency, Q-switched erbium:glass laser for remote sensing, Appl. Opt. 37(24), 5706-5709 (1998).

[5] G.I. Ryabtsev, M.V. Bogdanovich, A.I. Enzhievskiǔ, L.L. Teplyashin, A.P. Klishchenko, A.V. Pozhidaev, M.A. Shchemelev, A.G. Ryabtsev, A.S. Kraskovskiĭ, S.N. Titovets, K.V. Yumashev, A.M. Malyarevich, O.S. Dymshits, and A.A. Zhilin, Erbium-glass slab laser with transverse diode pumping, J. Opt. Technol. 75, 704-707 (2008).

[6] L.V. Shachkin, Passively Q-switched Yb, Er:phosphate glass laser, Quantum Electron. 36(2), 106-110 (2006).

[7] J.J. Degnan, Optimization of passively Q-switched lasers, IEEE J. Quantum Electron. 31(11), 1890-1901 (1995).

[8] J.J. Degnan, D.B. Coyle, and R.B. Kay, Effects of thermalization on Q-switched laser properties, IEEE J. Quantum Electron. 34(5), 887-899 (1998).

[9] N.P. Barnes and B.M. Walsh, Amplified spontaneous emission application to Nd: YAG lasers, IEEE J. Quantum Electron. 35(1), 101-109 (1999).

[10] H. Lu, Timing jitter caused by amplified spontaneous emission in mode-locked solid-state lasers, Opt. Commun. 183, 243-248 (2000).

[11] G.L. Zhi, Zh. Xiong, N. Moore, G.C. Lim, W.L. Huang, and D.X. Xuang, Amplified spontaneous emission effects in a passively Q-switched diode-pumped Nd: $\mathrm{YVO}_{4}$ laser, J. Opt. Soc. Am. B 21(8), 1479-1485 (2004).

[12] M.V. Bogdanovich, G.I. Ryabtsev, A.I. Yenzhyieuski, L.I. Burov, A.G. Ryabtsev, M.A. Shchemelev, and A.S. Smal, Amplified luminescence and generation dynamics of the diode pumped erbium-ytterbium laser, Lithuanian J. Phys. 47(4), 421-428 (2007).

[13] M. Hercher, An analysis of saturable absorbers, Appl. Opt. 6(5), 165-172 (1967).

[14] E. Tanguy, C. Larat, and J.P. Pocholle, Modelling of the erbium-ytterbium laser, Opt. Commun. 153, 172183 (1998).

[15] W. Koechner, Solid-State Laser Engineering, Springer Series in Optical Sciences Vol. 1, 6th ed. (Springer, Berlin, 2006).

[16] Y.V. Volk, A.M. Malyarevich, K.V. Yumashev, V.N. Matrosov, T.A. Matrosova, and M.I. Kupchenko, Anisotropy of nonlinear absorption in $\mathrm{Co}^{2+}: \mathrm{MgAl}_{2} \mathrm{O}_{4}$ crystal, Appl. Phys. B 88, 443-447 (2007). 


\title{
DIODAIS KAUPINAMO PASYVIAI MODULIUOTOS KOKYBĖS ERBIO LAZERIO DINAMIKOS YPATUMAI, INDUKUOTI SUSTIPRINTA SAVAIMINE EMISIJA
}

\author{
M.V. Bogdanovich ${ }^{\text {a }}$, A.V. Grigor'ev ${ }^{\text {a }}$, V.V. Kabanov ${ }^{\text {a }}$, Y.V. Lebiadok ${ }^{a}$, G.I. Ryabtsev ${ }^{\text {a }}$, A.G. Ryabtsev ${ }^{\text {b }}$,

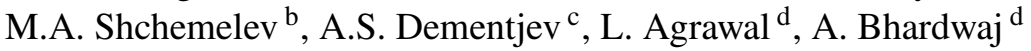 \\ ${ }^{\text {a } B a l t a r u s i j o s ~ n a c i o n a l i n e ̀ s ~ m o k s l u ~ a k a d e m i j o s ~ B . I . ~ S t e p a n o v o ~ f i z i k o s ~ i n s t i t u t a s, ~ M i n s k a s, ~ B a l t a r u s i j a ~}$ \\ ${ }^{\mathrm{b}}$ Baltarusijos valstybinis universitetas, Minskas, Baltarusija \\ ${ }^{\mathrm{c}}$ Fiziniu ir technologijos mokslu centro Fizikos institutas, Vilnius, Lietuva \\ ${ }^{\mathrm{d}}$ Lazeriu mokslinis technologinis centras, Delis Indija
}

\section{Santrauka}

Tirta sustiprintos savaiminės emisijos (SSE) ittaka diodais skersai kaupinamo erbio-iterbio stiklo lazerio su Co:špinelio kokybès moduliatoriumi dinaminėms charakteristikoms. Nustatytas lazerio su pasyviuoju kokybės moduliatoriumi SSE rezonatoriaus nuostolių koeficientas. Apibrèžtos SSE rezonatoriaus nuostolių koeficiento priklausomybės nuo aktyviojo elemento ilgio, išvado veidrodžio atspindžio koeficiento ir pasyviojo kokybès moduliatoriaus pradinio pralaidumo. Lazerio dinamika modeliuota remiantis balansinių lygčių, užrašytu jonų užpildos apgražos tankiams ir fotonų skaičiams, rinkiniu, atsižvelgiant i sustiprintą savaiminę emisiją. Parodyta, kad atsižvelgimas į SSE neturi didesnès įtakos lazerio išvado impulso energijai ir trukmei. Rasta, kad lazerio issijungimo laiko ir impulsų kartojimosi dažnio pokyčiai, atsižvelgus i SSE, pakinta $5-10 \%$. 